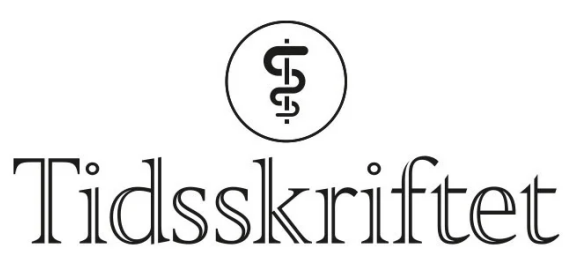

DEN NORSKE LEGEFORENING

\title{
G. Raknes svarer
}

KOMMENTAR

\section{GUTTORM RAKNES}

guttorm.raknes@relis.no

Guttorm Raknes er overlege ved RELIS Nord-Norge.

Forfatteren har ikke oppgitt noen interessekonflikter.

Takk til Mette Haase Moen for innspill til min artikkel (1) om hva man bør kalle kunstige progestagener.

Hun viser til at "gestagen» er innarbeidet i relevante fagmiljøer i Norden. Poenget er at «gestagen» har blitt brukt som betegnelse på både progestagener generelt og syntetiske progestagener, og at begrepsbruken er tilfeldig. Hvis en entydig terminologi er ønskelig, er progestin det eneste alternativet. Ved søk på «progestin» i medisinske forskningsdatabaser og på Internettet generelt, vil man nesten utelukkende få treff hvor syntetiske progestagener omtales.

Jeg innser at innføring av «progestin» som foretrukket term vil være utfordrende hvis det er sterk motvilje mot å gå bort fra «gestagen» i ledende fagmiljøer innen gynekologisk endokrinologi.

\section{LITTERATUR}

1. Raknes G. Progestageners terminologi. Tidsskr Nor Legeforen 2021; 141. doi:10.4045/tidsskr.21.0o66. [CrossRef]

Publisert: 16. august 2021. Tidsskr Nor Legeforen. DOI: 10.4045/tidsskr.21.0529

(C) Tidsskrift for Den norske legeforening 2023. Lastet ned fra tidsskriftet.no 26. april 2023. 